\title{
Value of Butyrylthiocholine Assay for Identification of Cholinesterase Variants
}

\author{
P. K. DAS and J. LIDDELL \\ From the Department of Clinical Chemistry, Guy's Hospital, London S.E. 1
}

Two unusual variants of cholinesterase (acylcholineacylhydrolase, 3.1.1.8) have been recognized by the use of differential inhibitors (Kalow and Genest, 1957; Harris and Whittaker, 1961). A third variant, the silent gene, determines an absent or greatly reduced serum cholinesterase level in the affected homozygote (Liddell, Lehmann, and Silk, 1962). These variants are alleles, and the affected homozygote is usually discovered because of an unexpected sensitivity to the muscle relaxant suxamethonium. Another variant, not an allele of the first group, is recognized by gel electrophoresis (Harris et al., 1963) and has not been investigated in this paper.

Inhibitor studies on the first group have used an assay with benzoylcholine as substrate (Kalow and Lindsay, 1955). The results obtained with the different genotypes are summarized in Table I. Two nomenclatures have been proposed. Both are given in the Table, and that of Goedde and Baitsch (1964) has been used in this paper.

Ellman et al. (1961) described a cholinesterase assay using acetylthiocholine. This has the disadvantage that acetylthiocholine is hydrolysed by

Received 26 January 1970. acetycholinesterase as well as cholinesterase, while the butyryl analogue is relatively specific for cholinesterase (Myers, 1953). This paper describes the use of a butyrylthiocholine assay for investigating the cholinesterase variants.

\section{Material and Methods}

Sera of known genotype. $\mathrm{Ch}_{1}{ }^{\mathrm{v}}$ homozygotes were individuals with normal inhibition values in the standard benzoylcholine assay. The $\mathrm{Ch}_{1}{ }^{\mathrm{D}}$ homozygote used in the preliminary work had characteristic inhibition values in the benzoylcholine assay, and a family study was compatible with this genotype. The $\mathrm{Ch}_{1}{ }^{\mathrm{F}}$ homozygote has been previously reported by Liddell, Lehmann, and Davies (1963). The sera used in the latter half of the results had again been identified by the benzoylcholine assay, and were from suxamethonium-sensitive propositi or their relatives. Many of the samples were provided by Professor H. Lehmann, Addenbrooke's Hospital, Cambridge, and Dr. Mary Whittaker, King's College, London.

Butyrylthiocholine assay. The principle of the method is that thiocholine produced by substrate hydrolyis reacts with 5-5' dithio-bis (2-nitrobenzoate) (DTNB) to give the nitrobenzoate anion absorbing strongly at $408 \mathrm{~m} \mu$.

TABLE I

NOMENCLATURE AND BIOCHEMICAL CHARACTERISTICS OF CHOLINESTERASE GENOTYPES AT $\mathrm{Ch}_{1}\left(\mathrm{E}_{1}\right)$ LOCUS

\begin{tabular}{|c|c|c|c|c|c|}
\hline $\begin{array}{l}\text { Goedde and } \\
\text { Baitsch (1964) }\end{array}$ & $\begin{array}{c}\text { Motulsky } \\
(1964)\end{array}$ & $\begin{array}{l}\text { Dibucaine } \\
\text { No. }\end{array}$ & $\begin{array}{c}\% \\
\text { Inhibition } \\
\text { by } \\
\text { R02-0683 }\end{array}$ & $\begin{array}{l}\text { Fluoride } \\
\text { No. }\end{array}$ & $\begin{array}{l}\text { Alcohol } \\
\text { No. }\end{array}$ \\
\hline $\begin{array}{r}\text { Homozygotes } \\
\mathrm{Ch}_{1} \mathrm{U} \mathrm{Ch}_{1} \mathrm{U} \\
\mathrm{Ch}_{1} \mathrm{DCh}_{1} \mathrm{D} \\
\mathrm{Ch}_{1} \mathrm{Ch}_{1} \mathbf{F} \\
\mathrm{Ch}_{1} \mathrm{Ch}_{1} \mathrm{~s} \\
\mathrm{Ch}_{1} \mathrm{Ch}_{1}\end{array}$ & $\begin{array}{l}E_{1}{ }^{u} E_{1} u \\
E_{1}^{a} E_{1}^{a} \\
E_{1}^{f} E_{1}^{f} \\
E^{s} E_{1} s\end{array}$ & $\begin{array}{c}77-83 \\
15-25 \\
64-67 \\
-\end{array}$ & $\begin{array}{c}95 \\
10 \\
75-86 \\
-\end{array}$ & $\begin{array}{c}57-68 \\
20-25 \\
34-35 \\
-\end{array}$ & $\begin{array}{c}156-189 \\
36-61 \\
-\end{array}$ \\
\hline $\begin{array}{r}\text { Heterozygotes } \\
\mathrm{Ch}_{1} \mathrm{UCh}_{1}^{\mathrm{D}} \\
\mathrm{Ch}_{1} \mathrm{Ch}_{1} \mathrm{~F} \\
\mathrm{Ch}_{1} \mathrm{Ch}_{1} \mathrm{C} \\
\mathrm{Ch}_{1} \mathrm{Ch}_{1} \mathrm{Ch} \\
\mathrm{Ch}_{1} \mathrm{Ch}_{1} \mathrm{~s} \\
\mathrm{Ch}_{1} \mathrm{FCh}_{1} \mathrm{~s}\end{array}$ & $\begin{array}{l}E_{1}^{u} E_{1} a \\
E_{1}^{u} E_{1}^{f} \\
E_{1}^{u} E_{1}^{s} \\
E_{1}^{a} E_{1} \\
E_{1}^{a} E_{1} s \\
E_{1}^{f} E_{1}^{s}\end{array}$ & $\begin{array}{l}52-69 \\
71-78 \\
77-83 \\
47-53 \\
15-25 \\
64-67\end{array}$ & $\begin{array}{c}58-76 \\
97-95 \\
95 \\
47-61 \\
10 \\
75-86\end{array}$ & $\begin{array}{l}42-55 \\
50-55 \\
57-68 \\
31-39 \\
20-25 \\
34-35\end{array}$ & $\begin{array}{c}106-148 \\
145-166 \\
156-189 \\
99-122 \\
36-61 \\
-\end{array}$ \\
\hline
\end{tabular}


$2.9 \mathrm{ml}$. aliquots of $0.27 \mathrm{mM}$ DTNB (Sigma) in

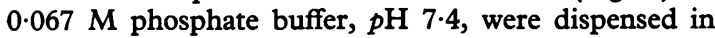
$5 \mathrm{ml}$. disposable plastic containers. 10 or $20 \mu$ l. plasma and $100 \mu 1.225 \mathrm{mM}$ butyrylthiocholine iodide (KochLight Laboratories) were added. The increase in optical density at $408 \mathrm{~m} \mu$ was measured in a Unicam Sp 800 recording spectrophotometer. The constant temperature cell housing was maintained at $25^{\circ} \mathrm{C}$. The final concentration of butyrylthiocholine iodide was $7.5 \mathrm{mM}$. One unit of activity was that producing the hydrolysis of 1 micromole substrate in 1 minute at $25^{\circ} \mathrm{C}$. The molar extinction coefficient of the thiocholine DTNB reaction product at $408 \mathrm{~m} \mu$ was found to be 13,600 . Therefore: units $/ \mathrm{ml} .=\Delta / \mathrm{min} \times 221 / \mu \mathrm{l}$. of sample. The $\mathrm{Q}_{10}$ of cholinesterase in this assay was found to be 1.9. Temperature correction could therefore be made by adding or subtracting $9 \%$ for each ${ }^{\circ} \mathrm{C}$. variation of the reaction mixture from $25^{\circ} \mathrm{C}$.

The spontaneous hydrolysis of butyrylthiocholine under these conditions was found to give an increase in optical density of less than $0.005 /$ minute. This could usually be ignored but was measured and used to correct the results when appropriate. Red cell haemolysates had a hydrolytic activity of approximately $0.3 \%$ of normal plasma.

Inhibitors. The following inhibitors were used: dibucaine hydrochloride (Koch-Light); sodium fluoride, AR (BDH); R02-0683 (Hoffman La Roche); the dimethylcarbamate of (2 hydroxy-5-phenylbenzyl) trimethyl ammonium bromide; n-Butanol (Fison; May and Baker; BDH: AR, special for chromatography and specially purified for the determination of 17-ketosteroids).

\section{Results}

Substrate concentration. The effect of the substrate concentration on the cholinesterase activity of sera from $\mathrm{Ch}_{1}{ }^{\mathrm{U}}, \mathrm{Ch}_{1}{ }^{\mathrm{D}}$, and $\mathrm{Ch}_{1}{ }^{\mathrm{F}}$ homozygotes was determined (Fig. 1).

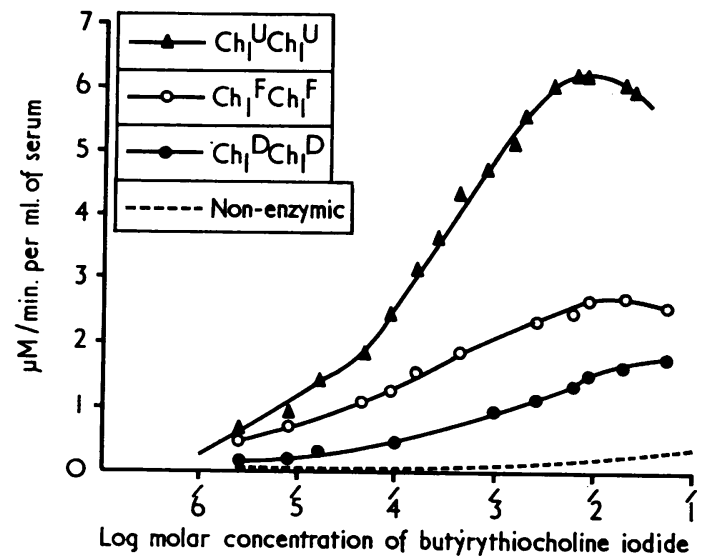

Fig. 1. The effect of butyrylthiocholine concentration on the rate of hydrolysis produced by sera from $\mathrm{Ch}_{1}{ }^{\mathrm{U}} \mathrm{Ch}_{1} \mathrm{U}(\boldsymbol{\Delta}), \mathrm{Ch}_{1}{ }^{\mathrm{D}} \mathrm{Ch}_{1} \mathrm{D}$ (๑), $\mathrm{Ch}_{1}{ }^{\mathrm{F}} \mathrm{Ch}_{1} \mathrm{~F}(\mathrm{O})$ individuals.
TABLE II

VALUES FOR $\mathrm{Km}$ AND OPTIMAL SUBSTRATE CONCENTRATION

\begin{tabular}{c|c|c}
\hline Genotype & $\underset{\mathrm{Km}}{(\mathrm{mM} / \text { litre })}$ & $\begin{array}{c}\text { Optimal } \\
\text { Substrate } \\
\text { Concentration } \\
\text { (mM/litre) }\end{array}$ \\
\hline $\mathrm{Ch}_{1}{ }^{\mathrm{U}} \mathrm{Ch}_{1} \mathrm{U}$ & 0.145 & 7.5 \\
$\mathrm{Ch}_{1} \mathrm{Ch}_{1}^{\mathrm{D}}$ & 0.895 & 14 \\
$\mathrm{Ch}_{1} \mathrm{~F} \mathrm{Ch}_{1} \mathrm{~F}$ & 0.095 & 8.0 \\
\hline
\end{tabular}

The values for $\mathrm{Km}$ and optimal substrate concentration are given in Table II.

A concentration of $7.5 \mathrm{mM}$ butyrylthiocholine was chosen for the subsequent investigations. With all three genotypes the change in the optical density with time was found to be linear up to $0 \cdot 40$. Variation in DTNB concentration in the range 0.1 to $0.8 \mathrm{mM} /$ litre was found to produce no significant change in the result.

Dibucaine inhibition. The inhibition produced by varying concentrations of dibucaine on sera from the $\mathrm{Ch}_{1} \mathrm{U}, \mathrm{Ch}_{1}{ }^{\mathrm{D}}$, and $\mathrm{Ch}_{1}{ }^{\mathrm{F}}$ homozygotes was measured using the above assay (Fig. 2). The results were similar to those obtained with benzoylcholine as substrate. Optimum differentiation of the three sera was obtained with $100 \mu \mathrm{M}$ dibu caine instead of the $10 \mu \mathrm{M}$ concentration used witho benzoylcholine.

R02-0683 inhibition. The inhibition produced by varying concentrations of this inhibitor on sera from the three homozygotes was measured (Fig. 3). The inhibitor and serum were added to the DTNB in phosphate buffer and pre-incubated for 2 hours at room temperature before adding substrate. The activity was compared with sera similarly pre-incubated without inhibitor. The results were identical with those obtained using benzoylcholine.

Fluoride inhibition. The effect of fluoride was investigated in a manner similar to that for dibucaine (Fig. 4).

When benzoylcholine was used, the usual enzyme was strongly inhibited, the $\mathrm{Ch}_{1}{ }^{\mathrm{D}}$ variant weakly inhibited, and the inhibition of the $\mathrm{Ch}_{1}{ }^{\mathrm{F}}$ variant was intermediate (Table I). With butyrylthiocholine the $\mathrm{Ch}_{1}{ }^{\mathrm{D}}$ variant was most strongly inhibited, the usual enzyme less so, and the $\mathrm{Ch}_{1}{ }^{\mathrm{F}}$ variant least of all.

Butanol inhibition. Whittaker (1968a, b) showed that low concentrations of alcohols activated cholinesterase, and higher concentrations inhibited when benzoylcholine was used as a sub- 

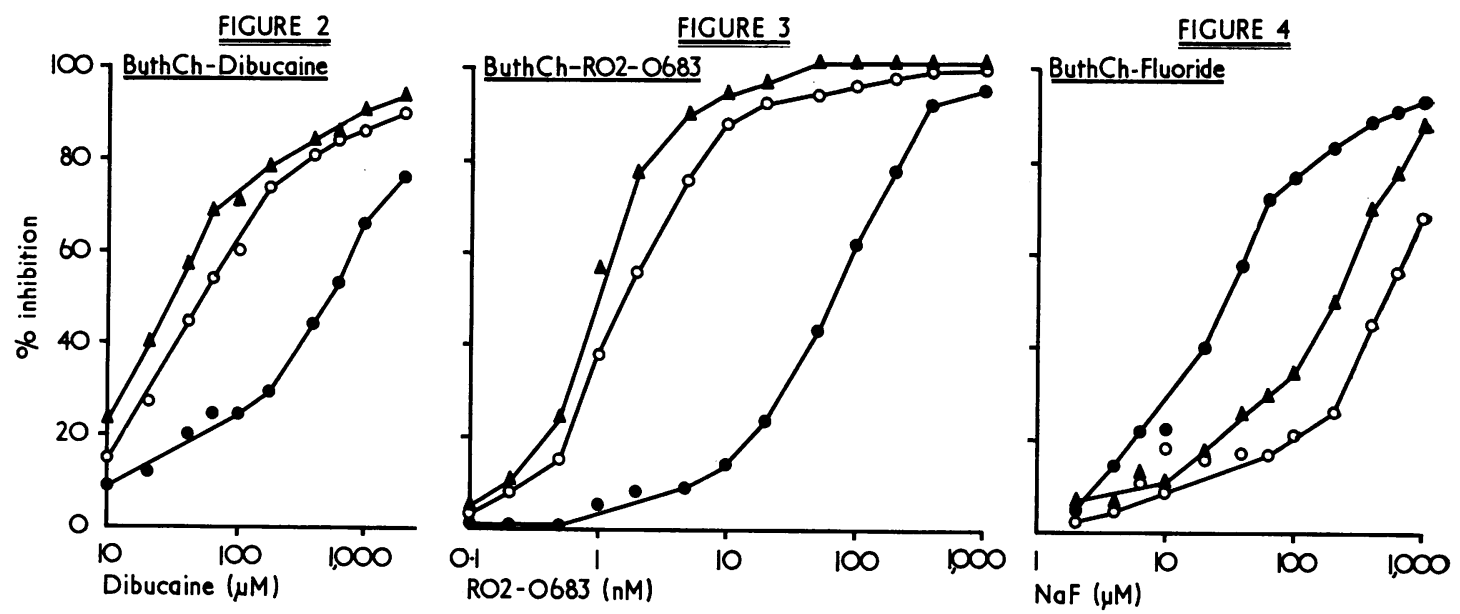

Fig. 2. The effect of dibucaine concentration on butyrylthiocholine hydrolysis by sera from $\mathrm{Ch}_{1}{ }^{\mathrm{U}} \mathrm{Ch}_{1}{ }^{\mathrm{U}}(\boldsymbol{A}), \mathrm{Ch}_{1}{ }^{\mathrm{D}} \mathrm{Ch}_{1}{ }^{\mathrm{D}}(\bullet)$, and $\mathrm{Ch}_{1}{ }^{\mathrm{F}} \mathrm{Ch}_{1} \mathrm{~F}$ $(O)$ individuals.

FIG. 3. The effect of R02-0683 concentration on butyrylthiocholine hydrolysis by sera from $\mathrm{Ch}_{1}{ }^{\mathrm{U}} \mathrm{Ch}_{1} \mathrm{U}(\boldsymbol{A}), \mathrm{Ch}_{1}{ }^{\mathrm{D}} \mathrm{Ch}_{1}{ }^{\mathrm{D}}(\boldsymbol{\theta})$, and $\mathrm{Ch}_{1}{ }^{\mathrm{F}} \mathrm{Ch}_{1}{ }^{\mathrm{F}}$ $(O)$ individuals.

FIG. 4. The effect of fluoride concentration on butyrylthiocholine hydrolysis by sera from $\mathrm{Ch}_{1}{ }^{\mathrm{U}} \mathrm{Ch}_{1} \mathrm{U}(\boldsymbol{A}), \mathrm{Ch}_{1}{ }^{\mathrm{D}} \mathrm{Ch}_{1}{ }^{\mathrm{D}}(\boldsymbol{O})$, and $\mathrm{Ch}_{1}{ }^{\mathrm{F}} \mathrm{Ch}_{1}{ }^{\mathrm{F}}$ $(O)$ individuals.

strate. There was a differential effect on the variants and $1 \%$ butanol gave the clearest distinction between the $\mathrm{Ch}_{1}{ }^{\mathrm{U}}$ and the $\mathrm{Ch}_{1}{ }^{\mathrm{D}}$ variant. The $\mathrm{Ch}_{1}{ }^{\mathrm{F}}$ variant was not clearly distinguished from $\mathrm{Ch}_{1} \mathrm{U}$.

It was found that higher concentrations of butanol were required to produce a comparable effect when butyrylthiocholine was used as substrate. For instance, $5 \%$ butanol activated usual cholinesterase to about $140 \%$ of the original activity and inhibited the activity of the enzyme from a $\mathrm{Ch}_{1}{ }^{\mathrm{D}}$ homozygote to $30 \%$ of the original level. This concentration of butanol in the benzoylcholine assay produced virtually complete inhibition of all three variants.

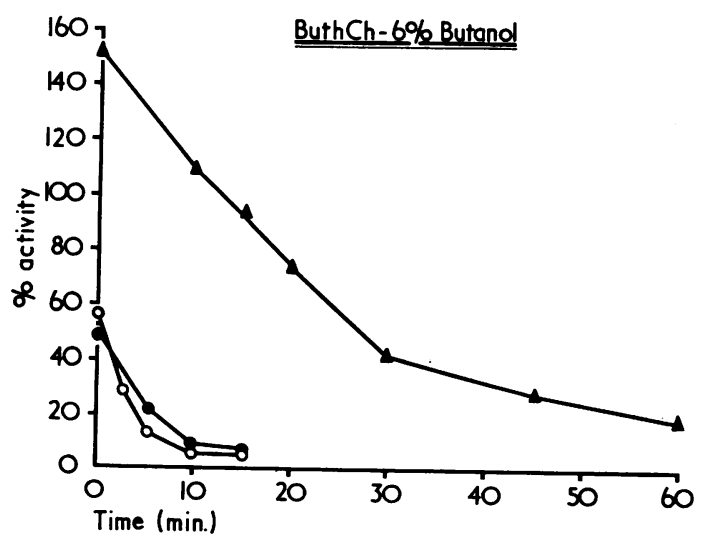

FIG. 5. The effect of varying periods of preincubation with $6 \%$ butanol on the butyrylthiocholine hydrolysis by sera from $\mathrm{Ch}_{1} \mathrm{U}^{\mathrm{C}} \mathrm{Ch}_{1} \mathrm{U}$ ( $\triangle), \mathrm{Ch}_{1}{ }^{\mathrm{D}} \mathrm{Ch}_{1}{ }^{\mathrm{D}}(\boldsymbol{O})$, and $\mathrm{Ch}_{1}{ }^{\mathrm{F}} \mathrm{Ch}_{1}{ }^{\mathrm{F}}(\mathrm{O})$ individuals.
With $6 \%$ butanol (the limit of solubility of butanol), there was a progressive loss of activity when the serum was pre-incubated with the DTNB/butanol/ phosphate buffer mixture before the addition of butyrylthiocholine. This loss of activity was slower with the usual enzyme, than with both the $\mathrm{Ch}_{1}{ }^{\mathrm{D}}$ and $\mathrm{Ch}_{1}{ }^{\mathrm{F}}$ homozygotes (Fig. 5). After 15 minutes, about $90 \%$ of the activity of the usual cholinesterase remained, and less than $10 \%$ with the $\mathrm{Ch}_{1}{ }^{\mathrm{D}}$ and $\mathrm{Ch}_{1}{ }^{\mathrm{F}}$ variants. Identical results were obtained with butanol from 3 different manufacturers, including that purified for steroid estimations and for chromatography. Purification of the butanol by distillation did not affect the results. The activity could not be recovered by dialysis against DTNB/phosphate buffer.

A similar result was obtained with $25 \%$ ethanol.

Differentiation of genotypes. The effect of the above inhibitors on the butyrylthiocholine assay of a number of sera of different genotypes was investigated.

The following conditions were used:

(1) Dibucaine $\mathrm{HCl}$. The addition of $30 \mu \mathrm{l}$. $10 \mathrm{mM}$ solution to $2.9 \mathrm{ml}$. DTNB phosphate buffer giving a final concentration of $100 \mu \mathrm{M}$.

(2) R02-0683. $30 \mu 1.1 \mu M \quad$ R02-0683 was added to $2.9 \mathrm{ml}$. DTNB/phosphate buffer. 10 or $20 \mu \mathrm{l}$. sera was added and incubated at room temperature for 2 hours. The activity was compared with that produced by similar incubation in the absence of inhibitor. 
(3) Fluoride. Estimated as for dibucaine $\mathrm{HCl}$, giving a final concentration of $100 \mu \mathrm{M}$ sodium fluoride.

(4) Butanol. The DTNB was dissolved in 6\% butanol in phosphate buffer. 10 or $20 \mu l$. serum was added to $2.9 \mathrm{ml}$. butanol/DTNB/phosphate buffer at room temperature. $100 \mu$ l. substrate was added precisely 15 minutes later. The activity was compared to that of the same sera incubated in the absence of butanol.

The results are shown in Table III.

TABLE III

EFFECT OF DIBUCAINE, R02-0683, SODIUM FLUORIDE, AND BUTANOL ON

BUTYRYLTHIOCHOLINE HYDROLYSING ACTIVITY OF 36 SERA OF KNOWN GENOTYPE: IN EACH CASE RANGE OF RESULTS IS GIVEN, WITH MEAN IN BRACKETS

\begin{tabular}{|c|c|c|c|c|c|}
\hline \multirow[b]{2}{*}{ Genotype } & \multirow{2}{*}{$\begin{array}{l}\text { No. } \\
\text { of } \\
\text { Sera }\end{array}$} & \multicolumn{3}{|c|}{$\%$ Inhibition } & \multirow{2}{*}{$\begin{array}{c}\% \\
\text { Activity } \\
\text { with } \\
\mathbf{6} \% \\
\text { Butanol }\end{array}$} \\
\hline & & $\begin{array}{l}\text { Dibucaine } \\
100(\mu \mathrm{m})\end{array}$ & $\begin{array}{c}\text { R02-0683 } \\
(10 \mathrm{~nm})\end{array}$ & $\begin{array}{l}\text { Fluoride } \\
(100 \mu \mathrm{m})\end{array}$ & \\
\hline $\mathrm{Ch}_{1} \mathrm{U}^{\mathrm{C}} \mathrm{Ch}_{1} \mathrm{U}$ & 10 & $82-88$ & 94-99 & $40-50$ & $94-108$ \\
\hline $\mathrm{Ch}_{1}{ }^{\mathrm{D}} \mathrm{Ch}_{1}{ }^{\mathrm{D}}$ & 12 & $\begin{array}{c}14-30 \\
(22)\end{array}$ & 5-12 & $\begin{array}{c}70-81 \\
(76)\end{array}$ & $\begin{array}{l}3-7 \\
(5)\end{array}$ \\
\hline $\mathrm{Ch}_{1}{ }^{F} \mathrm{Ch}_{1}{ }^{\mathrm{F}}$ & 3 & $60-73$ & $71-75$ & $30-35$ & $1-5$ \\
\hline $\mathrm{Ch}_{1}{ }^{\mathrm{U}} \mathrm{Ch}_{1}{ }^{\mathrm{D}}$ & 5 & $\begin{array}{c}(64) \\
60-68\end{array}$ & $\begin{array}{c}(73) \\
66-74\end{array}$ & $\begin{array}{c}(32) \\
44-60\end{array}$ & $\begin{array}{c}(3) \\
70-78\end{array}$ \\
\hline $\mathrm{Ch}_{1}{ }^{\mathrm{U}} \mathrm{Ch}_{1}{ }^{F}$ & 4 & $\begin{array}{c}70-79 \\
(75)\end{array}$ & $\begin{array}{c}81-92 \\
87)\end{array}$ & $\begin{array}{c}37-41 \\
(39)\end{array}$ & $\begin{array}{c}70-77 \\
(74)\end{array}$ \\
\hline $\mathrm{Ch}_{1}{ }^{\mathrm{D}} \mathrm{Ch}_{1}{ }^{\mathrm{F}}$ & 2 & $\begin{array}{c}59-63 \\
(61)\end{array}$ & $\begin{array}{c}58-69 \\
(63)\end{array}$ & $\begin{array}{c}(39) \\
47-52 \\
(50)\end{array}$ & $\begin{array}{c}(74) \\
10-12 \\
(11)\end{array}$ \\
\hline
\end{tabular}

\section{Discussion}

The butyrylthiocholine assay is inherently more sensitive than the benzoycholine method because the hydrolytic activity against the former is greater, and because the molar absorptivity of the nitrobenzoate anion is greater than that of benzoylcholine. The method can also be made much more sensitive by increasing the volume of serum up to $200 \mu \mathrm{l}$. if DTNB is first allowed to react with free thiol groups in the serum. This is impossible with benzoylcholine because protein absorbs strongly at $240 \mathrm{~m} \mu$. A butyrylthiocholine assay therefore requires only 2 minutes in a recording spectrophotometer instead of at least 5 minutes with benzoylcholine. This is important in survey work. The method is also sufficiently sensitive to detect the small cholinesterase-like activity in the sera of $\mathrm{Ch}_{1} \mathrm{~s}$ homozygotes.

The inhibitions of butyrylthiocholine hydrolysis by both dibucaine and R02-0683 were similar to that with benzoylcholine.

Fluoride produced different effects in the two methods. With benzoylcholine the variants are inhibited in the order $\mathrm{Ch}_{1}{ }^{\mathrm{U}} \mathrm{Ch}_{1}{ }^{\mathrm{F}} \mathrm{Ch}_{1}{ }^{\mathrm{D}}$, while with butyrylthiocholine the order was $\mathrm{Ch}_{1}{ }^{\mathrm{D}} \mathrm{Ch}_{1}{ }^{\mathrm{U}} \mathrm{Ch}_{1}{ }^{\mathrm{F}}$ (Fig. 4). Results similar to those with butyrylthiocholine were found when $5 \mathrm{mM}$ acetylthiocholine was substituted for the former. A theoretical explanation of the effect of the positively charged inhibitors such as dibucaine and R02-0683 is that the anionic site of the enzyme is less negatively charged in the $\mathrm{Ch}_{1}{ }^{\mathrm{D}}$ variant than in the usual cholinesterase. The fact that the negatively charged fluoride anion differentially inhibits benzoylcholine hydrolysis in a similar manner has been used as an argument against this hypothesis. The results with butyrylthiocholine weaken the objection. The mechanism of fluoride inhibition of enzymes is not known, and the difference between the inhibition of butyrylthiocholine and benzoylcholine cannot be explained.

The results obtained with butanol incubation may be due to denaturation of the enzyme and not to inhibition. The effect is not likely to be due to the presence of an unrecognized contaminant, as the same result was obtained with butanol from several different manufacturers and a redistilled sample. The failure to recover cholinesterase activity by dialysis and the similar result obtained with $25 \%$ ethanol both support the concept of denaturation Surgenor and Ellis (1954) precipitated a cholinesterase-containing fraction of human serum with $18 \%$ ethanol at $p \mathrm{H} 3.85$ and $-5^{\circ} \mathrm{C}$.

The benzoylcholine assay with different inhibitors does not clearly distinguish all genotypes. It is difficult to distinguish $\mathrm{Ch}_{1}{ }^{\mathrm{U}} \mathrm{Ch}_{1}{ }^{\mathrm{F}}$ individuals from $\mathrm{Ch}_{1}{ }^{\mathrm{U}} \mathrm{Ch}_{1}{ }^{\mathrm{U}}$ and $\mathrm{Ch}_{1}{ }^{\mathrm{U}} \mathrm{Ch}_{1}{ }^{\mathrm{D}}$, while $\mathrm{Ch}_{1}{ }^{\mathrm{F}}$ homozygotes may be confused with the $\mathrm{Ch}_{1}{ }^{\mathrm{U}} \mathrm{Ch}_{1}{ }^{\mathrm{D}}$ heterozygote (Table I). The butyrylthiocholine assay gave improved differentiation of most of these genotypes (see Table II). The best differentiation was obtained by using both the R02-0683 inhibition and butanol inactivation (Fig. 6). The only genotypes which are not clearly distinguished are $\mathrm{Ch}_{1}{ }^{\mathrm{U}} \mathrm{Ch}_{1}{ }^{\mathrm{D}}$ and $\mathrm{Ch}_{1}{ }^{\mathrm{U}} \mathrm{Ch}_{1}{ }^{\mathrm{F}}$. These can be differentiated by fluoride inhibition, though, as with the benzoylcholine assay, the distinction may not be easy in some cases. Butanol inactivation appears to be the most suitable method of detecting $\mathrm{Ch}_{1}{ }^{\mathrm{F}}$ gene frequencies in population surveys, as $\mathrm{Ch}_{1}{ }^{\mathrm{U}} \mathrm{Ch}_{1}{ }^{\mathrm{F}}$ individuals can be clearly distinguished from the normal population. Both benzoylcholine and butyrylthiocholine assays are not reliable for detecting the presence of the $\mathrm{Ch}_{1}{ }^{\mathrm{s}}$ gene as $\mathrm{Ch}_{1}$ s heterozygotes are phenotypically similar to the corresponding homozygote, i.e. $\mathrm{Ch}_{1}{ }^{\mathrm{U}} \mathrm{Ch}_{1} \mathrm{~s}$ individuals have the same inhibitor values as $\mathrm{Ch}_{1}{ }^{\mathrm{U}} \mathrm{Ch}_{1}{ }^{\mathrm{U}}$ subjects, while there is a conspicuous overlap in cholinesterase levels. 


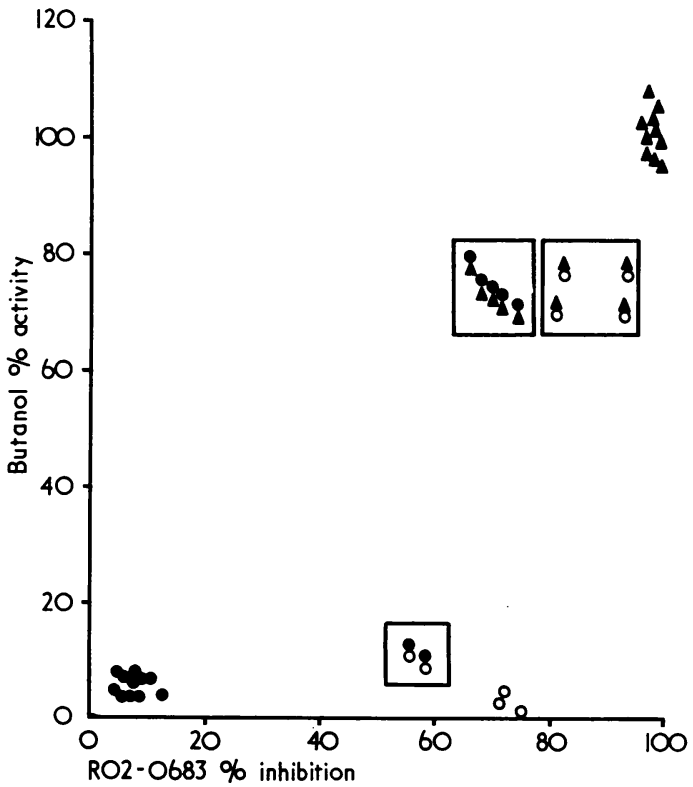

FIG. 6. A graph of the percentage inhibition produced by $10 \mathrm{nM} /$ litre $\mathrm{R} 02-0683$ and activity remaining after 15 minutes' incubation with $6 \%$ butanol for 36 sera of known genotypes.
A ${ }^{\mathrm{Ch}^{U}{ }_{1} \mathrm{Ch}_{1} \mathrm{U}}$
$\bigcirc \mathrm{Ch}_{1}{ }^{\mathrm{F}} \mathrm{Ch}_{1} \mathrm{~F}$
$\mathrm{Ch}_{1}{ }^{\mathrm{U}} \mathrm{Ch}_{1} \mathrm{D}$
$: \mathrm{Ch}_{1} \mathrm{U}^{\mathrm{U}} \mathrm{Ch}_{1} \mathrm{~F}$
$: \mathrm{Ch}_{1}{ }^{\mathrm{D}} \mathrm{Ch}_{1} \mathrm{~F}$

\section{Summary}

A cholinesterase assay using butyrylthiocholine as substrate has been investigated. It was found to be more rapid and convenient than the benzoylcholine technique.

The effect of dibucaine, R02-0683, fluoride, and butanol on sera from $\mathrm{Ch}_{1}{ }^{\mathrm{U}}, \mathrm{Ch}_{1}{ }^{\mathrm{D}}$, and $\mathrm{Ch}_{1}{ }^{\mathrm{F}}$ homozygotes was investigated. Dibucaine and R02-0683 gave similar results to those obtained with benzoylcholine.

Fluoride inhibition of butyrylthiocholine activity was more obvious with $\mathrm{Ch}_{1}{ }^{\mathrm{D}}$ than with $\mathrm{Ch}_{1}{ }^{\mathrm{U}}$ homozygote sera, the reverse of that found with benzoylcholine. Incubation with $6 \%$ butanol produced a rapid loss of activity with $\mathrm{Ch}_{1}{ }^{\mathrm{D}}$ and $\mathrm{Ch}_{1}{ }^{\mathrm{F}}$ homozygotes and a slow loss with normal sera.

The effect of $100 \mu \mathrm{M}$ dibucaine and fluoride, $10 \mathrm{nM}$ R02-0683, and $6 \%$ butanol on the butyrylthiocholine activity of 36 sera of known genotypes was investigated. These techniques gave a more precise identification of the cholinesterase genotype than the usual benzoycholine assay.

\section{REFERENCES}

Ellman, G. L., Courtney, K., Diane, Andres, V., and Featherstone, R. M. (1961). A new and rapid colorimetic determination of acetylcholinesterase activity. Biochemical Pharmacology, 7, 8897.

Goedde, H. W., and Baitsch, H. (1964). Nomenclature of pseudocholinesterase polymorphism. British Medical fournal, 2, 310.

Harris, H., Hopkinson, D. A., Robson, E. B., and Whittaker, Mary (1963). Genetical studies on a new variant of serum cholinesterase detected by electrophoresis. Annals of Human Genetics, 26, 359-382.

- , and Whittaker, Mary (1961). Differential inhibition of human serum cholinesterase with fluoride: recognition of two new phenotypes. Nature (London), 191, 496-498.

Kalow, W., and Genest, K. (1957). A method for the detection of atypical forms of human cholinesterase: determination of dibucaine numbers. Canadian fournai of Biochemistry and Physiology, 35, 339-346.

$\longrightarrow$, and Lindsay, H. A. (1955). A comparison of optical and manometric methods for the assay of human serum cholinesterase. Canadian fournal of Biochemistry and Physiology, 33, 568-589.

Liddell, J., Lehmann, H., and Davies, Daphne (1963). Harris and Whittaker's pseudocholinesterase variant with increased resistance to fluoride: a study of four families and identification of the homozygote. Acta Genetica et Statistica Medica, 13, 95-108.

-, Lehmann, H., and Silk, E. (1962). A 'silent' pseudocholinesterase gene. Nature (London), 193, 561-562.

Motulsky, A. E. (1964). Pharmacogenetics. Progress in Medical Genetics, 3, 49-74.

Myers, D. K. (1953). Studies on cholinesterase. 9. Species variation in the specificity pattern of the pseudocholinesterases. Biochemical fournal, 55, 67-79.

Surgenor, D. M., and Ellis, D. (1954). Preparation and properties of plasma proteins. Plasma cholinesterase. Fournal of the American Chemical Society, 76, 6049-6051.

Whittaker, Mary (1968a). The pseudocholinesterase variants: differentiation by means of alkyl alcohols. Acta Genetica et Statistica Medica, 18, 325-334.

- (1968b). Differentiation of human serum cholinesterase with n-butyl alcohol: recognition of new phenotypes. Acta Genetica et Statistica Medica, 18, 335-340. 